China Perspectives

45 | january-february 2003

Varia

\title{
Muslim Religious Education in China
}

Élisabeth Allès

\section{OpenEdition}

Journals

Édition électronique

URL : http://journals.openedition.org/chinaperspectives/230

DOI : 10.4000/chinaperspectives.230

ISSN : 1996-4617

\section{Éditeur}

Centre d'étude français sur la Chine contemporaine

\section{Édition imprimée}

Date de publication : 1 février 2003

ISSN : 2070-3449

\section{Référence électronique}

Élisabeth Allès, "Muslim Religious Education in China », China Perspectives [En ligne], 45 | januaryfebruary 2003, mis en ligne le 23 novembre 2006, consulté le 28 octobre 2019. URL : http:// journals.openedition.org/chinaperspectives/230 ; DOI : 10.4000/chinaperspectives.230

Ce document a été généré automatiquement le 28 octobre 2019

(c) All rights reserved 


\title{
Muslim Religious Education in China
}

\author{
Élisabeth Allès
}

\section{NOTE DE L'ÉDITEUR}

Translated from the French original by Michael Black

1 Despite their diversity, China's Muslims ${ }^{1}$ have been engaged for twenty years in a process of reaffirmation of their religion and identity ${ }^{2}$ : construction and renovation of mosques, dissemination of information on Islam in the world, translation of religious texts, etc ${ }^{3}$. As is the case in the rest of the Muslim world, their efforts have also been aimed at the field of education. At first, in the early 1980s, education was restricted to the mosque schools, but quickly, through individual or collective initiatives, both local and provincial, a number of private Arabic or Sino-Arabic schools, as well as many institutes, have opened all over the country. During the surveys we carried out in 2000 and 2002 in the provinces of Xinjiang, Gansu, Ningxia, Henan, Yunnan and in Hainan, we were able to observe the extraordinary growth of this Muslim teaching ${ }^{4}$.

2 Muslim religious leaders in China have always complained of their co-religionists' lack of religious knowledge: the flowering of schools does indeed answer a desire for education but also corresponds to the need to maintain and keep alive the Muslim religion among the faithful dispersed in the Chinese world, on whom twenty years of repression ${ }^{5}$ of all public religious activity have left their mark. Moreover, in the framework of the policy of reforms carried out in the field of education ${ }^{6}$ for over ten years (decisions taken in 1985 and 1993) which led to the decentralisation and privatisation of education, the objective of these Muslim initiatives is to compensate for the disengagement of the central state, and to make it possible for populations ${ }^{7}$ in difficult economic situations, and particularly for girls, to receive a basic education. Within the Chinese Muslim world, education and its modernisation are the objects of debate, controversy and competition between religious movements. These debates are not about the situation of the primary or secondary public schools, although it is a difficult situation, for these schools remain on a very low level despite the efforts made, 
particularly in the peripheral regions and along the frontiers ${ }^{8}$. According to Hui researchers, the situation of Hui public schools, as with other schools, has deteriorated, particularly with decentralisation. One of them gave a revealing description of a primary school in a Hui area of Xi'an, which does not seem to be the only one in this situation: "In order to be able to meet the needs of the school, whose expenses have increased considerably, the schoolyard has become a warehouse and a parking lot for taxis and lorries, and the school toilets have been made into public toilets". He also noted the difficulties encountered in paying the salary supplements of teachers, and lamented the fact that many of the pupils had to work after school: "It means that they can open their books only during classes". In 1997, the school lost one-third of its pupils. ${ }^{9}$ But since the public schools are the responsibility of the central and local authorities and the local population has little influence on their decisions, discussions tend to be about the private schools, over which the Muslims, having established them, have real power.

3 A study of the current development of denominational schools makes it possible to measure the degree of autonomy available to Muslims and to observe the way in which the political control of the state is exercised over this aspect of religious life nowadays. In fact education, a politically sensitive issue, is an area where many players confront each other, on a variety of levels.

In the Uygur autonomous region of Xinjiang, the authorities in Peking decided to impose strict and systematic control over education in the areas of both religion and language. Religious education, which had become widespread with the return of religious activities in the 1980s, was once again forbidden in 1996 following the troubles in the region (incidents in Khotan, Gulja, Bahren and Aksu). Since then there has been a slow recovery ${ }^{10}$. In 2002 an Imam was allowed to teach only one or two students $^{11}$, and only with the backing of the Bureau of Religious Affairs and of the local authorities, whereas, as we shall see, there can be close to a hundred students in the mosque schools in other Chinese provinces. The rule which states that one must be over 18 to study religion is, in Xinjiang, strictly applied. Moreover it is not legally possible to open a Muslim school like the ones in the rest of the country. Only one Koranic Institute (jingxueyuan), managed and controlled by the authorities, is authorised in Urumqi. Basic religious instruction is provided in the Arabic language. On the linguistic level, in May $2002^{12}$, Peking provided a reminder in the press of the decision-taken earlier but not yet really applied-to eliminate the Uygur language from higher education ${ }^{13}$. Moreover the poverty of Uygur families, especially in the oases in southern Tianshan, makes it impossible for their children to receive a normal education in public schools which have now become fee-paying, even for the theoretically obligatory first nine years of schooling. The result is that a Uygur child who does not come from an urban and relatively prosperous background has very little chance of being able to avail of an education beyond primary level, which he will usually have received in Uygur ${ }^{14}$. If a family seeks to compensate for this educational deficiency with religious schooling, they will have to wait until the child reaches the age of 18 and send him either abroad, in this case to Pakistan, if they can afford it, or to have him follow the course in a Koranic school in another part of China if they have been able to establish contact with the school ${ }^{15}$. The organisation of clandestine schools is indeed possible, but the risks are real. Thus, the limited opportunities for education mean, that in the streets of the cities, as in Khotan for example, 
numbers of young boys aged between 12 and 14 work as drivers of ramshackle taxi-carts pulled by donkeys in order to contribute to their families' needs. Moreover, even a young Uygur graduate of the University of Urumqi has but little hope of professional employment in the region, as his low linguistic competence in Chinese will prevent him obtaining a job, preference being given to Han Chinese speakers. In these hopeless situations, it cannot come as any surprise that young people seek to leave the area or are attracted by a modern discourse which preaches the unity of Islam and a return to the Caliphate ${ }^{16}$. A number of them, suspected of belonging to the Hizb it-Tahrir ${ }^{17}$ (Liberation) movement, were arrested $^{18}$ in the spring of 2001 in Xinjiang ${ }^{19}$.

5 In the other Chinese provinces, the situation is very different, in as much as it is mainly a case of Chinese-speaking Muslims (the Hui). The confrontation then takes place not only with the central state but more with the local authorities. Moreover religious education reveals the rivalries between Muslim religious movements.

From mosque school to private school

6 There are about $40,000^{20}$ mosques in China, each of which, in theory, has a school ${ }^{21}$. However, not all the ahong (Imams) ${ }^{22}$ of these places of worship have students. Apart from the authoritarian restrictions to be seen in Xinjiang, this can be due, in nonconflict situations, to the tiredness and advanced age of the ahong. In these circumstances, students can easily join another school nearby. While the average number of students can be estimated at twenty per mosque, some of them, which have space, better facilities and where the teaching of the ahong is renowned, can bring together a hundred students. In theory at least 18 years old ${ }^{23}$, these students are mainly boys, particularly in the provinces of the north-west. However the mosque schools are also open to girls when there are no mosques for women ${ }^{24}$ as in the provinces of the central plain. Some of the students have been to public school, up to the end of the second secondary syllabus (gaozhong); however a large number of them stopped at primary school or at the end of the first secondary school syllabus (chuzhong) and some are virtually illiterate in Chinese. They are natives of different regions and sometimes come from very far away. Tuition fees are paid for by the host community, as is accommodation, if the student's family is unable to find the money.

Some history

7 All through the history of Islam in China, as well as today, education has been a major issue. It is a question of maintaining communities of the faithful in an environment which is overwhelmingly non-Muslim. In the sixteenth century, schools were opened at the mosques to provide religious education called jintang jiaoyu (teaching of the room of the classics), characteristic of traditional Islam (laojiao) ${ }^{25}$, the content of which had been elaborated by an ahong from Shaanxi, Hu Dengzhou (1522-1597) ${ }^{26}$, on his return from a journey to Mecca. At the beginning of the twentieth century, the fundamentalist and reformist movement $i k h w a n{ }^{27}$, of Wahhabite inspiration, made the modernisation of education one of its watchwords, insisting at the time on the learning of Chinese and the education of women.

Other Muslim reformers involved in the intellectual ferment of the whole of Chinese society at the beginning of the twentieth century set up schools, such as the famous teacher's training college, Chengda ${ }^{28}$, whose objective was to provide modern teaching combining the joint study of Chinese and Arabic, of history, mathematics, and the sciences, and to promote the sending of students abroad. 
The classic syllabus in traditional Islam (laojiao) called for over ten years of study, with several ahong. The halifa ${ }^{29}$ learned Arabic and Persian, the basic texts (the haiti ${ }^{30}$, the zaxue ${ }^{31}$, the Koran, the sunna ${ }^{32}$, the tafsir ${ }^{33}$, the figh ${ }^{34}$ ) and carried on ${ }^{35}$ with deepening texts in both languages with an emphasis on Persian ${ }^{36}$, particularly in the case of Sufi teaching and of that dispensed by the female ahong. It was a teaching based on the master to disciple relationship, which favoured a deepening of the understanding of the texts and a broadening of knowledge. This course ended, as it does today, with a ceremony called "the taking of the vestment" (chuanyi) ${ }^{37}$ which marks the progression from the rank of student to that of ahong.

The situation today

With the revival of religious activity, the need to rejuvenate the ahong, and the pressure from reformed teaching, the form and content of the classical syllabus have been modified. The number of years of study has been reduced to four or five, and the special relationship between master and disciple is tending to dissipate, because of the sometimes rapid turnover among the ahong, but above all because of the increasing number of teachers. Where the content is concerned, teaching is limited to the learning of Arabic and knowledge of the basic texts, supplemented by a course on the religious policy of the state. Thus the modernisation of religious teaching takes into account one of the main criticisms made of the ahong of traditional Islam, which was that they are unable to express themselves in Arabic, and pronounce it with a strong Chinese intonation. Arabic is thus learned as a modern language and no longer simply as a written language, the sacred language of the Koran. In order to display the good level of Arabic of today's young Chinese, competitions in reading the Koran are regularly organised, at provincial and national levels, in the presence of dignitaries from the Muslim world. This improved language training is taking place at the expense of Farsi, which, nevertheless, still remains a language of study in the teaching of the female ahong and the Sufi brotherhoods. However, the texts required for the final examination being mainly in Arabic, works in Persian are tackled less and less frequently. All in all, while young students now have a real ability to speak Arabic, there is, on the other hand, to the regret of many ahong, a reduction in religious knowledge. The academic cycle ends with an examination supervised by the local Bureau of Religious Affairs, by a representative of the local branch of the Islamic Association, if there is one, and by the local ahong. After having taken the vestment, the new ahong is invited by a local community to come and officiate. This reformed teaching has spread to all the mosques in the last few years, whatever movement they belong to.

11 Since the 1990s, on the initiative of ahong or of lay teachers, some of the mosque schools, while remaining on the premises or close to the religious building, have changed into independent organisations with the establishment of a director and a specific administration ${ }^{38}$. Other schools are being built independently. They all have the status of a private or specialised school (sili xuexiao, zhuanye xuexiao, or zhuanke xuexiao).

12 These private schools have acquired considerable importance. Some are known for the numbers of their students, male and female, the diversity of their training, and the possibility they offer of following university education in China (in the foreign language sections) or abroad. They often go by names such as "Sino-Arabic school" (zhong a xuexiao), "Arabic language school" (ayu or alaboyu xuexiao), or "Muslim Culture School" (musilin wenhua xuexiao). These names sometimes convey a specific option; certain schools choose the name "Arabic School" in order to emphasise that their main 
objective is the teaching of the language; others add another component showing their religious commitment such as Muguang alaboyu xuexiao ("Muslim Light" School of Arabic) or else an Arabic word: Xida zhong a xuexiao (Xidayah (The Right Path) SinoArabic School). Others emphasise their characteristic identity: Huizu wenhua xuexiao (School of Hui Culture). Those responsible for the Dali School have, deliberately, not mentioned "Arabic School" or "Sino-Arabic", but use the concept of Muslim culture: Dali musilin wenhua zhuanke xuexiao (Dali Professional School of Muslim Culture). Indeed, their objective is not to restrict themselves to language learning, but to give the students as wide an awareness as possible of the contemporary world ${ }^{39}$. These designations show the tensions between what is specific to the Hui identity, what is part of the Muslim identity, and the desire to put Arabic in the forefront, but we cannot draw any general conclusions from this, for the choice of names depends not only on the founder(s) of the school, but also on the local community, on its history and on the circumstances of the moment.

It is difficult to have an exact idea of the number of these private schools in the whole of China. There are said to be twelve schools in Yunnan province ${ }^{40}$; for the other provinces, one can estimate that, where the number of Hui is relatively high ${ }^{41}$, there is a minimum of five or six schools. If one is to believe some young Hui students of this teaching, five schools are considered the most prestigious: one in Ningxia, two in Henan, and two in Yunnan. The content of the teaching is now largely identical; the differences lie in the facilities ${ }^{42}$, particularly in computers, and in the emphasis given to certain classes. The subjects taught include: Arabic, using textbooks produced in Peking or Shanghai; a more or less extensive basic religious education (Koran, Sunna, figh, tafsir), for which the books come from Saudi Arabia or Kuwait; the history of China and of Islam, with books published in Chinese and mostly written by Hui ${ }^{43}$. Lastly, there is a course called social sciences, dealing with Chinese legislation and religious policy in China. Some schools offer instruction in modern and classical Chinese, and even sometimes additional courses in English ${ }^{44}$ and computing. Studies are spread over four years with a final examination which only a few succeed in passing. The schools are often co-educational (but with separate classes) ${ }^{45}$; the students are aged between 18 and $25^{46}$, with girls making up more than half of those registered. They are accepted after having passed the final secondary level examination (chuzhong or gaozhong) or reached an equivalent level. The number of students averages a hundred and can reach three hundred in the biggest schools. More than half come from the province in question, but also from all over China, and although the majority are Muslims (Hui and Uygur), there are also young Han, or, depending on the region, other minzu (Li, Yi, etc.) who convert when their studies begin ${ }^{47}$. The study costs of the least wealthy are usually paid for ${ }^{48}$ by the host community. In poor areas, costs are limited to 200 yuan for four years; elsewhere fees average 400 to 500 yuan a year, to which must be added food and lodging costs of between 50 and 100 yuan per month. These modest fees are explained by the financial involvement of the local communities and also by the low levels of remuneration given to teachers, some of whom are retired and work for nothing. Salaries are calculated according to a person's family situation, geographical origins and training. Which is to say that a man who is the head of a family, who comes from another province from that of the school, and has studied abroad, will have the highest salary. Payments are in the range of 300 to 500 yuan a month. While the majority of teachers are men, about one-third are women. A noteworthy complementary activity is the regular publishing of a newspaper written by the teachers with the participation of 
the students. These publications are widely distributed in the mosques and in the other schools of each province and beyond; they are used to propagate theological ideas and to provide information on social issues.

"If we want to develop Islam, girls must be educated!"

14 The education of women, a preoccupation often spelt out by the ahong, is one of the major components of current developments ${ }^{49}$. Thus, evening and sometimes morning classes in the mosques, aimed at adult working or older women, bring together dozens of people and sometimes more. These classes are given by ahong ${ }^{50}$ of both sexes. An example is the evening school, called the women's school (nüxiao), in Sanya on the island of Hainan. This establishment consists of two main buildings, one being reserved for the young girls who follow the regular teaching of one of the village's mosques, the other being made up of four classrooms. The quiet of the day yields, at nine o'clock, to the buzz of comings and goings, and when the female ahong arrives, there rise the first sounds of the collective recitation of the surats of the Koran, sung out loud, surats which are repeated over and over in order to be remembered. There are about fifteen people in each classroom. The same evening classes are to be found in the women's mosques in the Central Plain and also in the women's mosque of Lanzhou (Gansu). A complete plan of action designed to favour the education of girls has gradually been put in place alongside the schools with regular courses. For example, instruction is given one evening a week in specially provided classrooms, or during the holidays in mosque schools, where one can see little girls of five or six learning the Arabic alphabet in chorus. Even more remarkable are those which, with few resources, manage to maintain instruction aimed at adolescent girls.

Let us take the example of a girls' school in Shuijinwan, a village in northern Yunnan, near Zhaotong. This very poor village is $90 \%$ Hui, whose resources are essentially agricultural. It is a village where there has never really been any education for girls despite the existence of a public school, to which families virtually only send boys ${ }^{51}$. The situation has apparently grown worse with the advent of family planning. In 1982, an ahong ikhwan ${ }^{52}$, along with a woman teacher from another part of Yunnan, decided to found a school for young girls in one of the mosques. This immediately had a hundred students. After having to move twice, the school found a permanent establishment in a former food factory. The son of the ahong took over, with the assistance of five young female teachers, and together they teach over 80 students aged between 12 and 20. The school is considered to be a minban, and receives funds from the local community; when things get too difficult the district authorities assign it a subsidy of 1,000 yuan for the year. The young girls pay no tuition fees, their families are too poor, the only costs are board and lodging (20 yuan per month) which some families cannot pay. The school adds up to 30 yuan per pupil per month. These conditions mean, of course, that the buildings remain dilapidated, the dormitories with floors of beaten earth are cleaned by the pupils, and the meals cooked by the older ones. The teachers are paid a salary of 150 to 200 yuan a month. All the pupils are boarders; they go home to their families only at weekends or on religious holidays. When one sees the harshness of life around it, the school seems a haven of peace, and it is without any doubt a protective place for girls. In principle, the pupils have attended public primary school, and in this school are preparing for the secondary school examinations (chuzhong and gaozhong), but because of infrequent attendance at primary school a remedial class is provided for the youngest. The day begins with exercise in the schoolyard and continues with teaching in Chinese (five hours a week) and the 
learning of Arabic (eight hours a week). These young girls also receive religious instruction which is increased in the third and fourth years. Few pupils manage to continue their studies, but it is notable that in 2002 four of them were able to go to a mosque school in Shandong.

For the young girls, the school is a way of getting out of their family environment. It is quite common to hear pupils recount their progress - sometimes rapid, from a few days to a year-from school to school: they stay in the one where they feel most comfortable. For others, it is a real source of hope. A young woman of 19, from a very religious Hui family in Xinjiang, told us how she had been obliged to stop going to primary school in order to help and support her sick mother. Her brothers and sisters were able to pursue their secondary studies normally, while she alone remained at home. When the family situation improved, she wanted to return to secondary studies, but no longer could; one of the religious schools in Yunnan then gave her a way out.

The Koranic Institutes

In parallel with private initiatives, the state has founded Koranic Institutes (yisilanjiao jingxueyuan) at provincial level, through the Department of Religious Affairs and the Islamic Association of China. Established between 1983 and 1987, they now number eight, all over China, in the cities of Shenyang, Lanzhou, Yinchuan, Xining, Kunming, Peking ${ }^{53}$, Urumqi and Zhengzhou. They have university status ${ }^{54}$ and their objective is to train ahong, teachers, and Arabic language translators. These Institutes receive major funding ${ }^{55}$, and one can admire the enormous new buildings which admit numbers of male and female students which are much lower than in the mosque schools or the private schools. The Zhengzhou Institute has only 90 students (47 male, 43 female). The students enter these Institutes at the end of the second secondary cycle (gaozhong) after an examination. Until 2001, the length of studies was only three years, but is now five. Fees are relatively high: even if a student can obtain a grant, they must pay 1,600 yuan for tuition and 140 or 150 yuan a month for lodging. On the other hand the monthly salary of teachers is around 1,200 yuan. In order to attract students, the Institutes, such as the one in Zhengzhou, seek to diversify the syllabus by opening specialised courses in calligraphy, for example, or in martial arts. A considerable number of Muslim parents do not particularly want to send their children there: on top of the selection process for admission and the cost of studies, they are wary of the kind of religious instruction given, since this is entirely controlled by the political authorities.

Religious education: a springboard for study abroad or for finding a job

Going abroad is an opening for these students who would have had no chance of being able to do so in the framework of public education (their families not being wealthy enough, or not being able to get into the best schools). When they return, having acquired a better knowledge of Muslim societies ${ }^{56}$, they relay the debates under way in the Muslim world: their approach to society and to the role of Muslims in the world, as well as their behaviour, often depend on where they have studied ${ }^{57}$.

For those who have not been lucky enough to go abroad, the normal syllabus leads to becoming an ahong; others become teachers or interpreters (in Canton and Shenzhen) or follow a university course at the Foreign Languages Department of Peking University. The young women, for their part, teach in private schools or can find a job in the kindergartens opened by local communities ${ }^{58}$. However, many Hui teachers and leaders emphasise that there are now more than enough ahong, and prefer to open 
other possibilities to the young. From this point of view, it is worth examining the experience of the Dali School. Situated in a small village near the south gate of the city the "Specialised School of Muslim Culture" (musilin wenhua zhuanke xuexiao) was founded by three retirees, two former high school teachers and a former school director. Having returned to their village, they were upset at the irrelevance of classical Koranic teaching to the needs of today and to changes in society. In 1991, they founded a school in a part of the mosque (laojiao), despite the reservations of the old ahong. As well modernised teaching, they decided to open a section entirely in Chinese in order to prepare students for the final examination for the teacher training university of Kunming (shifan daxue) ${ }^{59}$. In 2002, 13 of the 16 candidates registered passed the examination, which will make it possible for them to teach in a public establishment.

Education: a muffled battleground between religious movements

Islam in China, as elsewhere in the Muslim world, is not monolithic. It has been and continues to be influenced by many movements. While in past centuries there were struggles for influence between traditional Islam and the Sufis, or between the Sufi brotherhoods themselves, since the beginning of the twentieth century the confrontation has widened out to one between a fundamentalist and a modernist Islam, represented by the $i k h w a n$, and more recently to a more rigoristic movement called salafi (san tai) ${ }^{60}$. The places of confrontation are traditionally the mosque, and sometimes the street, but education has always been one of its main battlegrounds. Today, as in the past, the conflict can become very violent ${ }^{61}$; formerly disagreements concerned the interpretation of the Koran and religious practices. In our day, the debates have changed little, it is a question of returning to the purity of the origins, of reforming practices which have been overly adapted to local circumstances, of remaining faithful to the Koran and of advocating the unity of Islam. Education is thus by nature the place where these movements are expressed. It is generally on his return from a stay in the Holy Land that a man bearing a rejuvenated gospel introduces his teaching into a mosque school. His charisma, his ability to persuade and train disciples will be the driving force of the success of such a movement, as well, of course, as the social and political situation into which he fits. Consequently, after twenty years of religious activity, profound changes in Chinese society, the anxieties produced by social inequality resulting from economic development, the lack of bearings of many young people and the absence of any democratic political space, mean that a growing number of young people are attracted to the discourse of the salafi movement on the unity of Umma, and by the clarity and simplicity of its doctrine (a return to the faith of the elders (salaf) ${ }^{62}$. While there is here an attempt to find a kind of social morality, some ideals and a course of action for life-an attempt which is understandable after the preceding years of political campaigns and today's upheavals-, this rigoristic trend produces other effects, more surprising in the contemporary Chinese context, particularly for women. One becomes aware of it ${ }^{63}$ at the sight of young girls being educated in the schools of salafi inspiration, who are entirely veiled in black, with their faces covered. This is a singular sight, for the young girls of the religious schools generally only wear a simple headscarf (hijâb) and sometimes long dresses.

Religious education under surveillance

21 The question of religious education has preoccupied the Chinese authorities since long before September 11th. The increase in the number of schools, the growing numbers of students returning from Muslim countries, the circulation of the writings of reformers from the beginning of the century, which are now banned ${ }^{64}$, the situation in Xinjiang 
and also the activities of other movements such as those of the Christians and of the Falungong, have prompted the authorities to increase surveillance. Thus on April 23rd $2001^{65}$ they established, through the very official Islamic Association of China, a "Committee in charge of Islamic education affairs", considered to be a specialised commission (zhuanmen) at national level and made up of 16 members, with a Hui majority (10 out 16). The authorities have also provided themselves with an instrument to regain the upper hand and try to control not only the teaching but also the content of religious discourse: "Eliminating among the masses the false interpretations (wujie) and confusion (hunluan) about religious matters" ${ }^{16}$. The first public initiative took place in Xinjiang in August 2001 and was devoted to the presentation of a new book of sermons published by the Committee in July and strongly recommended ${ }^{67}$. Sermon competitions will be organised from now on, like those concerning the reading of the Koran. This committee is also responsible for the publishing of translations and of the textbooks for teaching. We have in fact been able to observe, in the private schools we visited, a kind of standardisation through the widespread use of the same books on language, history, etc. However the effectiveness of such methods is open to question, particularly in Xinjiang where the problem has never been of a religious kind. A significant event recently provided evidence of this: after a very official concert during which a poem exalting Uygur national sentiment was sung, a severe call to order ${ }^{68}$ was addressed to the Party cadres of the region, for an incident which manifestly had nothing to do with religion.

Thus while the Party is unable to exercise total control over the ideas in circulation, delegating their surveillance to the Muslims themselves seems to be a guarantee of restricting the growth of new movements. However, where the growth of the salafi is concerned, this calculation has so far been mistaken. In fact, the traditional independence of one mosque from another and the increasing autonomy of society make control more difficult. Consequently, between state intervention in matters of religion and the increasing forms of autonomy, there is an unstable balance, the duration of which is difficult to predict. Moreover, the exercise of this control will be all the more complicated because the government will not always be able to use the divisions of Islam among the various "nationalities". There has been much emphasis on the heterogeneousness of the situations of these "nationalities" and on the differences which divide them on historical, linguistic and cultural levels. These differences are indisputable and are visible to any observer; it is nevertheless true that not only are there exchanges between these groups, but that similar movements of revitalisation pass through them and transcend their boundaries.

\section{NOTES}

1. Islam in China today includes ten "nationalities" (minzu) containing about 18 million people. These are partly the Turkish or Turko-mongol speaking communities (Uygur, Kazakh, Kirghiz, Bao'an, Dongxiang, Tatar, Ouzbek, Salar) living in the provinces of the Northwest of China (Xinjiang, Gansu, Ningxia, Qinghai), a small group of Farsi speakers, 
the Tadjik in Xinjiang, and partly a population of 9 million Chinese speaking Muslims, the Hui, who are scattered all over China. From the religious standpoint Muslims in China are Sunnis of the Hanefite rite. Only the Tadjik are Ismaeli Chiites.

2. Dru C. Gladney, Muslim Chinese. Ethnic Nationalism in the People's Republic, Cambridge and London, Council on East Asian Studies, Harvard University Press, 1991, (1996, 3rd ed.); Françoise Aubin, "Chine”, in H. Chambert-Loir et C. Guillot, Le culte des saints dans le monde musulman, Etudes Thématiques, No. 4, Paris, EFEO, 1995, pp. 367-388.; Elisabeth Allès, Musulmans de Chine. Une anthropologie des Hui du Henan, Paris, EHESS, 2000.

3. E. Allès, L. Chérif-Chebbi, C. H. Halfon, "L'islam chinois, unité et fragmentation", in Archives des sciences sociales des religions, No. 115, 2001, pp. 26-28.

4. In the course of this research we were able to meet the authorities and the pupils of the mosque schools in the towns and villages we visited, of fifteen private schools and three Islamic institutes (jinxueyuan). The minban are village or collective schools under contract with the local authorities.

5. The first closings of mosques took place in 1958. Religious activities as a whole did not start again until after the beginning of the reforms undertaken by Deng Xiaoping in 1978.

6. See on this subject the special report "Education" in China Perspectives, No. 36, JulyAugust 2001.

7. Minority populations with nationality status ( $m i n z u)$ whose level of illiteracy is often higher than the national average. See the graph giving a summary by region of illiteracy among the non-Han populations. Thierry Pairault, 2001, "Formation initiale et développement économique”, China Perspectives, No. 36, July-August 2001, fig. 1, p. 6 8. Gerard A. Postiglione ed., China's National Minority Education. Culture, Schooling, and Development, New York and London, Falmer Press, 1999. On the education of Muslims in China, see especially in this volume the articles by Dru Gladney, "Making Muslims in China: Education, Islamicization and Representation", pp. 55-94, and Colin Mackerras, "Religion and the Education of China's Minorities", pp. 23-54.

9. Ma Bin, “Guanyu Xi'an huifang jiaoyu xianzhuang de sikao" (Reflections on the present situation of education in the Hui area of Xi'an), Huizu xuegan (Journal of Hui Studies), No. 1, 2001, pp. 199-205.

10. In August 2002 we observed in the towns of southern Tianshan the opening of mosques only during the hours of prayer, which made any teaching impossible. Only the great mosque of Id kah in Kashgar remained open to the public for tourist visits. 11. We were able to observe one exception to this rule. The ahong of a Hui mosque in Urumqi (Shaanxi mosque), which is the seat of the local Islamic association, has the privilege of having about twenty students. This privilege, granted for political reasons, poses a serious background problem of discrimination against other ahong, especially the Uygur ones.

12. AFP, Hong Kong, May 28th 2002.

13. While science studies were already in Chinese, Uygur was still regularly used in the other disciplines.

14. Each minzu uses its own language at primary school. The learning of Chinese (putonghua) generally begins in the last year of primary school and continues during secondary school at a rate of about three hours a week.

15. It is not unusual to see young Uygur boys and girls in the mosque schools in the provinces of central and southern China. 
16. To many Muslims an ideal model of the organisation of power, the Caliphate was abolished by Mustapha Kemal in 1924 .

17. This movement has been active in Central Asia since 1995. For its thinking, its history and its organisation see Ahmed Rashid, Asie centrale, champ de guerres, (original title: Jihad: The Rise of Militant Islam in Central Asia), Paris, Autrement, 2002, pp. 106-123; Olivier Roy, "Islamic Ferments and State Responses in Central Asia; Is there a Chinese Card?", in François Godement, La Chine et son Occident. China and its western Frontier, Paris, Centre Asie, Ifri, 2002, p.151.

18. The Economist, March 30th 2002, p. 26.

19. On the general situation in Xinjiang, see the reports by Amnesty International and Human Rights Watch.

20. The Islamic Association of China in 1995 officially listed 33,300 mosques, including 23,000 in Xinjiang. These figures are approximate, and according to the sources cited vary considerably, with observation in the field prompting higher estimates.

21. As well as the Koranic schools, there are martial arts schools in some mosques. 22. The term ahong (from the Persian akhund) is used in Chinese Islam for Imam. 23. Some schools have pupils as young as 16 .

24. These women's mosques are a particularity of Chinese Islam. Directed by women ahong, they have existed for several centuries, particularly in the Central Plain. See Elisabeth Allès, 2000, Musulmans de Chine. Une anthropologie des Hui du Henan, Paris, EHESS, chaps. XII-XIII; M. Jaschok, Shui Jingjun, The History of Women's Mosques in Chinese Islam: A Mosque of their Own, Richmond, Curzon Press, 2000.

25. Ancient teaching which corresponds to the term qadim (ancient) in Arabic or gedimu in Chinese transliteration.

26. This teaching is described by Françoise Aubin in: "L'enseignement dans la Chine islamique pré-communiste (du XVIe au milieu du XIXe siècle): entre affirmation identitaire et modernisme", in N. Grandin et M. Gaborieau éds., Madrasa, La transmission du savoir dans le monde musulman, Paris, Arguments, 1997, pp. 374-375.

27. On this movement and its development in China, see J. Lipman, 1997, Familiar Strangers: a History of Muslims in Northwest China, University of Washington Press, Seattle-London, pp. 208-211.

28. Jinan Chengda shifan xuexiao. This school was created in 1925 in one of the mosques in Jinan by Ma Songjing (one of the four great ahong in China in the Republican period). In 1929, the school was transferred to the Dongsi Mosque in Peking. It was among the first to send groups of students to the biggest university in the Muslim world, Al-Azhar in Cairo.

29. From the Arabic khalifah (successor) used in China as a term for a student in theology. The term generally used in Arabic for student is talib.

30. Excerpts from the surats of the Koran in Arabic, annotated in Chinese transliteration, and translated.

31. A collection of the precepts relating to the ablutions and prayers of the day. It is conceived like the haiti, in Chinese transliteration from the Arabic.

32. Deeds and sayings of the Prophet.

33. Exegesis of the Koran.

34. Islamic law. Includes the study of the four schools of law (Hanafite, Malakite, Shafeite, Hanbalite).

35. The complete syllabus comprised 13 works.

36. The search for knowledge in Islam traditionally followed this slow path. 
37. Today this ceremony is a highpoint in the cohesion of the community. It brings together not only the members of the local community and their ahong, but also the ahong of the mosque where the candidate comes from. For the occasion, the latter wears a long green coat and an imposing white turban.

38. This structure had already been initiated in the 1920s, for example in the Chengda School previously mentioned.

39. Interview, July 2002.

40. Jacqueline Armijo-Hussein, 1999, "Resurgence of Islamic Education in China", ISIM Newsletter, No. 4, p. 12.

41. The city of Yinchuan (Ningxia) alone has three Sino-Arabic schools open at present.

42. These schools generally began with very little equipment. The teaching materials were sometimes merely notebooks assembled by the teacher.

43. Some of the writers are retired teachers who devote most of their time to this dissemination of knowledge. A compilation of their texts on the history of Islam and of Islam in China was published in 2000, in a work entitled Musilin zhongdeng zhuanye xuexiao hanyu jiaocai, which is used in most of the schools.

44. Even in a laojiao mosque in Henan, we observed an English class in which Arabic was used as the language of translation.

45. Except in the Northwest (Ningxia, Gansu) where it is the schools which are separate.

46. In some schools the students can be up to 28 or 30 years old.

47. If one lives outside a major city, the difficulties in getting access to secondary or university education are the same, regardless of nationality.

48. As an overall figure for the schools we visited, 10 to $20 \%$ of the students are supported by the local community, but in certain regions, as in the north of Yunnan, 40 to $50 \%$ of the students need help.

49. Leila Cherif, "Ningxia, l'école au féminin", Etudes Orientales, No. 13/14, 1994, pp. 156-162; Constance-Hélène Halfon, "Femme et musulmane à Lanzhou, au Gansu", Etudes Orientales, No. 13/14, 1994, pp. 151-155.

50. In the Yunnan, the term shimu is used for a woman ahong.

51. This situation is not unique. The same thing can be seen in Ningxia, for example.

52. The other ahong of the town also belong to this movement.

53. A Koranic Institute already existed in 1955 in the Niu Jie area. Zhou Xiefan and Sha Qiuzhen, Yilisilanjiao zai Zhongguo (The Islamic Religion in China), Peking, Huawen chubanshe, 2002, p. 201. The present Institute opened 1986.

54. Interview, in April 2002, with the directors of the Institute in Zhengzhou. Presentation of the Zhengzhou Institute in Henan Musilin, April 15th 2002, p. 23. 55. The Institute in Yinchuan has been particularly well endowed, with a subsidy of 1 million yuan in 1986 as well as bank loan facilities. Via the Islamic Association of China, funds also came from the World Islamic Development Bank.

56. Armo-Hussein notes a certain disillusionment in the face of the realities of life in modern Muslim society, 1999, op. cit.. We ourselves have met young women who, having gone Saudi Arabia with their husbands, did not wish to remain there.

57. We have been able to have very open discussions with ahong who had returned from Iran or from Damascus, whereas they have felt a much more closed off and rigid attitude on the part of ahong who had studied at Medina, and who, for example, avoid looking an unveiled woman in the face when they speak to her. 
58. For example in Zhengzhou (Henan), a kindergarten has been opened in the mosque on Huayuan Street. It is attended by 100 children, of whom 80 are Hui. Likewise, the mosque on Maohuo Street in Zhaodong (Yunnan) has opened a kindergarten in buildings it leases from the Catholic church opposite the mosque.

59. The subjects taught are classical and modern Chinese, foreign literature, philosophy and pedagogy.

60. Dru Gladney, "The Salafiyya Movement in Northwest China: Fundamentalism among the Muslim Chinese?", in Leif Manger ed., Muslim Diversity: Local Islam in Global Contexts, Surrey, Curzon Press, Nordic Institute of Asian Studies, No. 26, 1999, pp. 102-149.

61. Lipman Jonathan N., "Sufism in the Chinese Courts: Islam and Qing Law in the Eighteenth and Nineteenth Centuries", in F. De Jong and B. Radtke eds., Islamic Mysticism Contested. Thirteen Centuries of Controversies and Polemics, Brill, 1999, pp. 553-575; Cherif-Chebbi, Leila, "L'Yihewani, une machine de guerre contre le soufisme en Chine?" in F. DeJong and B. Radtke eds., ibidem, 1999, pp. 576-602.

62. The salafi take into consideration only the Koran and those Hadith which are considered to be authentic, and reject the schools of law which have grown up in Sunnism. It is common to hear young halifa say with a certain admiration: "They know the texts better!".

63. We have observed this phenomenon in Yunnan.

64. On can still find, but only very rarely and very discreetly, translations of Mohamed Abduh in Chinese, as well as, in Xinjiang, texts by Maududi, but in Urdu.

65. Zhongguo musilin, 2001, No. 3, p. 8.

66. The complete definition of the tasks of this committee is presented in Zhongguo musilin, No. 3, 2001, p. 14.

67.Xinbian "wo er zi” (wa'z in Arabic) yanjiangti (New Compilation of Speeches for Sermons), Peking, Zongjiao wenhua chubanshe, 2001, 136 pp.

68. South China Morning Post, September 20th 2002. 